\title{
PENGEMBANGAN MANAJEIMEN SUMBER DAYA MANUSIA TERHADAP PENINGKATAN MUTU PENDIDIKAN
}

\author{
H. Abd. Wahid Tahir
}

Kakanwil Kementerian Agama Sulawesi-Selatan

\begin{abstract}
Increasing human resources is becoming increasingly important for institutions that are used to gain better control through their own business. Institutions should demonstrate that they are able to provide quality education to learners. For every institution, quality is the main agenda and quality improvement is the most important task. Nevertheless, some people think of quality as a concept full of riddles. Quality is regarded as confusing and difficult to measure. Quality in a person's view is sometimes different from that of others. So it is not strange if experts do not have the same conclusions about how to create good and quality institutions. Human resource management in quality improvement aims to change the institution that operates it into a sincere team, without conflict and internal competition, to achieve a single goal, namely to satisfy customers.
\end{abstract}

Keywords: Management, Human Resources, Improvement and Quality

\section{PENDAHULUAN}

$\mathrm{P}$

embinaan pendidikan yang dilakukan oleh Kementerian Agama selama ini masih perlu langkah-langkah penyesuaian yang strategis. Dalam proses peningkatan kualitas sumber daya manusia, pendidikan memegang peran yang sangat penting dan harus merupakan suatu proses yang terintegrasi dengan proses peningkatan kualitas pembinaan madrasah secara keseluruhan. Salah satu peran penting pendidikan adalah menyiapkan sumber daya manusia yang berkualitas sesuai dengan perubahan zaman agar tidak terjadi kesenjangan antara realitas dan idealitas. ${ }^{1}$

Upaya peningkatan kualitas pengelolaan pendidikan pada madrasah, melalui standar nasional pendidikan yaitu; mengenai Standar Kompetensi Lulusan, Standar Isi, Standar Proses, Standar Pendidikan dan Tenaga Kependidikan, Standar Sarana dan Prasarana, Standar Pengelolaan, Standar Pembiayaan Pendidikan, dan Standar Penilaian Pendidikan, sedang dilakukan dan akan dilakukan secara terus menerus. ${ }^{2}$ Upaya tersebut merupakan agenda pemerintah melalui Kementerian Agama yang diarahkan agar setiap satuan pendidikan madrasah selalu berupaya untuk memberikan jaminan kualitas

\footnotetext{
${ }^{1}$ Abdul Rahman Shaleh, Penyelenggaraan Madrasah (Cet. II; Jakarta: Dharma Bakti, 2013), h. ix.

${ }^{2}$ Lebih lanjut baca, apabila setiap lembaga penyelenggara pendidikan selalu berupaya untuk memberikan jaminan kualitas dan upaya ini secara terus menerus dilakukan maka diharapkan kualitas pendidikan pada madrasah secara keseluruhan di seluruh Indonesia akan terus meningkat. Departemen Agama, Profil Madrasah Masa Depan (Cet. I; Jakarta: Direktorat Jenderal Pendidikan Islam, 2006), h.19.
} 
kepada pihak-pihak yang berkepentingan, yaitu suatu jaminan agar setiap penyelenggara pendidikan di madrasah sesuai dengan apa yang seharusnya dan sesuai pula dengan harapan masyarakat. Madrasah mempunyai peran penting dalam peningkatan mutu pendidikan dan sumber daya manusia (SDM), sesuai dengan cirinya sebagai lembaga pendidikan agama, secara ideal madrasah berfungsi dalam penyiapan sumber daya manusia yang berkualitas tinggi, baik dalam penguasaan terhadap ilmu pengetahuan dan teknologi (IPTEK) maupun dalam hal karakter, sikap moral, iman dan taqwa (IMTAQ), serta penghayatan dan pengamalan ajaran agama. ${ }^{3}$

Secara ideal menurut penulis lembaga pendidikan berfungsi membina dan menyiapkan peserta didik yang berilmu, berteknologi, berketerampilan tinggi dan sekaligus beriman dan beramal saleh, dalam kerangka perwujudan fungsi ideal pendidikan di madrasah dalam meningkatkan kualitas SDM tersebut, sistem pendidikan haruslah senantiasa mengorientasikan diri untuk menjawab kebutuhan dan tantangan yang muncul dalam masyarakat sebagai konsekwensi logis dari perubahan. Pembangunan yang berlangsung demikian cepat dalam beberapa dasawarsa terakhir telah mengantarkan Indonesia ke dalam barisan Negara-negara yang disebut NICS (New Industrialized Countries) atau Negara-negara industri baru. Meski Indonesia telah mencapai kemajuan seperti itu, pembangunan tentu saja masih jauh dari pada selesai. Bahkan sebaliknya, Indonesia harus semakin meningkatkan momentum pembangunannya. ${ }^{4}$ Untuk itu, tidak ada alternative lain, kecuali penyiapan SDM yang berkualitas tinggi, menguasai ilmu pengetahuan dan teknologi, serta keahlian dan keterampilan. Hanya dengan tersedianya SDM yang berkualitas tinggi itu, Indonesia bisa survive di tengah pertarungan ekonomi politik Internasional sesuai dengan UndangUndang RI No. 20 tahun 2003 tentang pendidikan nasional.

\section{HAKIKAT MANAJEMEN SDM DALAM PENINGKATAN MUTU}

Pengertian manajemen adalah sebuah proses, pelaksanaan untuk mencapai suatu tujuan tertentu diselenggarakan dan diawasi. Jadi manajemen pendidikan lebih terfokus kepada upaya manajerial yang meliputi planning, organizing actuatin dan controlling. Pengertian ini sama dengan apa yang telah dikemuakan Geoge R. Terry yang telah dikemukakan sebelumnya. Berdasar dari uraian di atas, maka manajemen mencakup kegiatan untuk mencapai tujuan, dan dalam mencapai tujuan tersebut diadakanlah tindakan-tindakan yang telah ditetapkan sebelumnya. Tindakan-tindakan yang ditetapkan tersebut berupa pengetahuan tentang apa yang harus dilakukan, menetapkan cara bagaimana melakukannya, memahami bagaimana harus melakukan dan mengukur efektifitas dari usaha-usaha yang diinginkan. Sedangkan Sumber Daya Manusia adalah

${ }^{3}$ Lihat Syed Muhamad Naquib al Attas, Konsep Pendidikan dalam Islam : Suatu Rangka Pikir Pembimbing Filsafat Pendidikan Islam (Cet. I; Bandung: Mizan, 2009), h. 35-74.

${ }^{4}$ Abuddin Nata, Manajemen Pendidikan Mengatasi Kelemahan Pendidikan Islam di Indonesia (Cet. I; Jakarta: Kencana Prenada Media Group, 2008), h. 1. 
potensi untuk menggunakan pikiran dan karya yang dimiliki dan digunakan secara optimal demi keberhasilan individu atau organisasi setelah potensi tersebut dikembangkan. ${ }^{5}$ Sumber daya manusia sebagai pengalaman belajar yang terorganisir dalam jangka waktu tertentu untuk meningkatkan kemungkinan memperbaiki, pertumbuhan kinerja.

Sedangkan istilah peningkatan mutu dalam Kamus Besar Bahasa Indonesia mengandung arti ukuran baik untuk suatu benda, kadar, taraf atau derajat, untuk kependidikan adalah derajat kecerdasan, kualitas, meningkatkan pendidikan. ${ }^{6}$ Selanjutnya kata prestasi dalam Kamus Ilmiah Populer, berarti kualitas, derajat atau tingkat. ${ }^{7}$ Sejalan dengan itu, Daulat Tampubolon mengartikan prestasi sebagai paduan sifat-sifat produk, yang menunjukan kemampuannya dalam memenuhi kebutuhan pelanggan lansung atau tidak lansung baik kebutuhan yang dinyatakan maupun yang tersirat, masa kini dan masa depan. ${ }^{8}$

Berdasakan dari uraian di atas, dapat dipahami bahwa yang dimaksud penulis manajemen sumber daya terhadap peningkatan mutu adalah suatu sistem implementasi dalam menjalankan suatu usaha pendidikan yang berusaha memaksimumkan daya saing melalui penyempurnaan terus menerus dalam meningkatkan kualitas pendidikan secara totalitas.

Peningkatan sumberdaya terhadap peningkatan Mutu dan profesionalisme guru dan tenaga kependidikan juga dijadikan sebagai prioritas utama dalam pembangunan pendidikan, karena tenaga pendidik (guru) merupakan salah satu elemen penting dalam sistem pendidikan, bahkan komponen-komponen lain tidak akan berarti banyak apabila guru dalam proses pembelajaran tidak mampu berinteraksi dengan peserta didik dengan baik dan secara sempurna apalagi tidak mampu menghasilkan peserta didik yang berkualitas. ${ }^{9}$ Sebagaimana yang termaktub di dalam Undang-Undang No.20 Tahun 2003 Tentang Sistem Pendidikan Nasional menyatakan bahwa; Pendidik dan tenaga kependidikan berkewajiban:

a. Menciptakan suasana pendidikan yang bermakna, menyenangkan, kreatif, dinamis dan dialogis;

b. Mempunyai komitmen secara profesional untuk meningkatkan mutu pendidikan;

${ }^{5}$ Soetjipto, Budi W., dkk., Paradigma Baru Manajemen Sumber Daya Manusia (Cet. II; Yogyakarta: Amara Book, 2012), h. 21.

${ }^{6}$ Departemen Pendidikan Nasional, Kamus Besar Bahasa Indonesia (Jakarta: Balai Pustaka, 2008), h. 604.

${ }^{7}$ Pius A. Partanto dan M Dahlan al-Barry, Kamus llmiah Poputer (Surabaya: Arkola, 1994), h. 505.

${ }^{8}$ Daulat P. Tampubolon, Perguruan Tinggi Bermutu: Paradigma Baru Manajemen Pendidikan Tinggi Menghadapi Abad ke-21 (Cet. I; Jakarta: PT. Gramedia Pustaka Utama: 2011), h. 108

${ }^{9}$ Kementerian Pendidikan Nasional, Dirjen Peningkatan Mutu Pendidik dan Tenaga Kependidikan(PMPTK), Direktorat Tenaga Kependidikan Penilaian Kinerja Guru dan kompetensi evaluasi Pendidikan, th. 2008, h. 1. 
c. Member teladan dan menjaga nama baik lembaga, profesi dan kedudukan sesuai dengan kepercayaan yang diberikan kepadanya. ${ }^{10}$

Pada hakekatnya keberhasilan dan ketercapaian tujuan pendidikan nasional tergantung pada sumber daya manusia yang ada di sekolah/madrasah, yaitu kepala madrasah, guru, siswa, pegawai tata usaha, dan tenaga kependidikan lainnya serta dukungan manajemen mutu yang lebih efektif, selain itu harus pula didukung oleh sarana dan prasarana yang bermutu. Semua sumber daya manusia yang terlibat didalam pengelolaan pendidikan harus memiliki kualitas yang memadai, karena untuk membentuk manusia yang sesuai dengan tujuan pembangunan nasional, yaitu meningkatkan kualitas manusia dan seluruh masyarakat Indonesia yang maju dan modern, dibutuhkan tenaga pendidik dan tenaga kependidikan yang berkualitas dan handal.

Wardiman Djoyonegoro dalam E. Mulyasa mengemukakan bahwa sedikitnya terdapat tiga syarat utama yang harus diperhatikan dalam pembangunan pendidikan agar dapat berkontribusi terhadap peningkatan kualitas sumber daya manusia terutama dalam peningkatan prestasi siswa di madrasah aliyah, yakni: Sarana dan prasarana yang modern, buku yang berkualitas, dan guru/tenaga kependidikan yang profesional. ${ }^{11}$ Dalam organisasi kependidikan, kepala madrasah merupakan pimpinan puncak yang bertanggung jawab atas kelangsungan organisasi tersebut. Kepala madrasah merupakan salah satu komponen pendidikan yang paling berperan dalam meningkatkan kualitas pendidikan. ${ }^{12}$ Oleh sebab itu kepala madrasah bertanggung jawab atas manajemen pendidikan secara mikro, yang secara langsung berkaitan dengan proses pembelajaran di madrasah.

Wahjosumidjo mengemukakan bahwa keberhasilan kepemimpinan berkaitan erat dengan peningkatan prestasi siswa dan tingkat kepedulian serta keterlibatan seorang pemimpin terhadap kedua orientasi; pertama yaitu tentang apa yang telah dicapai oleh organisasi (organizational achievement) yang meliputi produksi, pendanaan, kemampuan adaptasi dengan program-program inovatif, dan kedua, yaitu pembinaan terhadap organisasi( Organizational maintenance) yang berkaitan dengan kepuasan bawahan dan semangat kerja. ${ }^{13}$

Dari uraian di atas, menunjukkan bahwa keterlibatan seluruh komponen dalam pengelolaan madrasah membutuhkan respon strategis dari berbagai unsur dan elemen masyarakat di dunia pendidikan. Para pakar pendidik yang berkecimpung di lembaga-

${ }^{10}$ Departemen Agama RI, Direktorat Jenderal Pendidikan Islam, op.cit, h. 8.

${ }^{11}$ E. Mulyasa, Menjadi guru Profesional: Menciptakan Pembelajaran Kreatif dan Menyenangkan (Cet.X; Bandung: Remaja Rosdakarya, 2011), h. 3.

${ }^{12}$ Dedi Supriyadi, Mengangkat citra dan martabat Guru (Cet. I; Yogyakarta: Adicipta Karya Nusa, 1998) h. 346.

${ }^{13}$ Wahjosumidjo, Kepemimpinan Kepala Sekolah (Cet. I; Jakarta: Raja Grafindo Persada, 2010) h. 49. 
lembaga pendidikan, baik pada pendidikan dasar dan menengah maupun di lembaga pendidikan tinggi, sudah saatnya merumuskan sebuah sistem dan pola penyelenggeraan pendidikan yang lebih bermutu, demokratis, kompetitif dan profesional, baik untuk melanjutkan pendidikan kejenjang lebih tinggi maupun memasuki dunia kerja. ${ }^{14}$ Lembaga-lembaga pendidikan keagamaan seperti madrasah aliyah, beban yang ditanggungnya semakin berat, di samping keberadaannya lebih historis sebagai lembaga pendidikan/akademik maupun sebagai lembaga dakwah, ${ }^{15}$ belakangan dituntut lebih dari itu menjadi lembaga profesional untuk mengembangkan akademik dan keterampilan tertentu sebagai bekal bagi peserta didik dalam menghadapi era persaingan global.

Perhatian manajemen pada peningkatan sumberdaya manusia suatu produk dalam dasawarsa ini terus meningkat pesat. Perkembangan dimulai dari dunia industri dan dianggap berhasil dalam meningkatkan efisiensi dan penjualan produksi dunia industri tersebut. Keberhasilan itu, merambah ke setiap kegiatan yang menggunakan manajemen untuk meningkatkan kinerja organisasi. ${ }^{16}$ tidak ketinggalan juga pada dunia pendidikan. Manajemen peningkatan sumberdaya manusia merupakan salah satu pola manajerial dalam upaya merespon masyarakat yang cepat dan terus menerus. ${ }^{17}$

Manajemen peningkatan sumberdaya manusia mengandung dua aspek kajian, pertama kajian dalam dataran konsep suatu pendekatan dalam menjalankan usaha khususnya pada segmen pendidikan yang berupaya memaksimalkan daya saing melalui penyempurnaan secara terus-menerus atas produk, manusia, proses, dan lingkungan organisasi atau lembaga, dan kedua kajian mencakup cara penyampaiannya, yang mencakup pada sepuluh karakteristik dari manajemen mutu yaitu berfokus pada pelanggan (internal dan eksternal); berobsesi tinggi pada kualitas; menggunakan pendekatan ilmiah; menyempurnakan kualitas secara berkesinambungan; pendidikan dan pelatihan; menerapkan kebebasan yang terkendali; memiliki kesatuan tujuan; serta melibatkan dan memberdayakan pendidik dan peserta didik. Kedua aspek tersebut harus menjadi kesatuan yang utuh sehingga usaha dalam mencapai tujuan dapat diperoleh

${ }^{14}$ Majelis Pertimbangan dan Pemberdayaan Pendidikan Agama dan Keagamaan (MP3A), Direktorat Jenderal Pendidikan Agama Islam, Kementerian Agama RI, Revitalisasi Madrasah dalam Menghadapi Persaingan Global, Jurnal Volume 1, 2 Maret 2006, h. 8.

${ }^{15}$ Secara historis, perkembangan madrasah pada mulanya memang diawali sebagai misi dakwah dalam rangka memenuhi hajat masyarakat untuk melaksanakan ajaran agamanya (ibadah mahdah dan ibadah ghairu mahdah) secara holistic (kasffah). Madrasah mempunyai karakter yang spesifik dan unik, karena bukan hanya melaksanakan misi dakwah dan pendidikan, tetapi juga mempunyai tugas untuk memberikan bimbingan dan tuntunan keagamaan kepada masyarakat sekitarnya, sehingga dalam realitas kehidupan sosial, madrasah menjadi milik masyarakat dan menyatu dengan nilai-nilai atau norma-norma sosial yang telah hidup dan berkembang di kalangan masyarakat. ibid.

${ }^{16}$ Lihat William Mantja, Manajemen Peningkatan Mutu Pendidikan. (Cet. I: Jakarta: LIPI, 2000), h. 10 .

${ }^{17}$ Lihat Ibid, h. 11. 
secara optimal. ${ }^{18}$

\section{IMPLEMENTASI MANAJEMEN SDM DALAM PENINGKATAN MUTU}

Implementasi manajemen sumberdaya manusia dalam dunia pendidikan memang belum banyak dilakukan, bahkan ada sementara kalangan yang meragukan efektifitas manajemen peningkatan SDM dalam dunia pendidikan. Sementara kalangan yang lain menganggap manajemen sumberdaya manusia sebagai suatu harapan yang cerah bagi dunia pendidikan. Aplikasi manajemen SDM di madrasah mengundang perdebatan. Beberapa pakar pendidikan mempertanyakan kelayakan dan kesesuaian konsep manajemen SDM dengan karakteristik madrasah. Pengamat tersebut berargumen bahwa manajemen SDM merupakan konsep yang sulit untuk dievaluasi dalam dunia pendidikan khususnya di Madrasah. ${ }^{19}$

Menurut Wina Sanjaya ada empat bidang utama prinsip-prinsip manajemen SDM yaitu:

1. Penerapan manajemen SDM untuk peningkatan fungsi administrasi dan operasi secara luas untuk mengelola madrasah secara keseluruhan. Penerapan konsep manajemen SDM, khususnya pada madrasah Aliyah dalam meningkatkan fungsi administrasi, dimaksudkan untuk memberi penguatan terhadap manajemen peningkatan mutu yang selama ini telah dilakukan oleh madrasah, seperti manajemen Berbasis Sekolah/Madrasah (MBS/M) atau Manajemen Peningkatan Mutu Berbasis Sekolah/Madrasah (MPMBS/M), yang oleh sebagian pakar manajemen pendidikan menyatakan bahwa dasar dari manajemen ini dikembangkan dari konsep manajemen SDM, yang pada mulanya diterapkan pada dunia bisnis. Fungsi-fungsi Manajemen pada Madrasah merupakan faktor penting dan strategis dalam rangka kemajuan Madrasah sebagai suatu lembaga pendidikan formal yang diharapkan dapat mencapai tujuan institusionalnya yang memiliki sumber daya manusia (SDM) yang memadai dan dikelolah dengan sistem Administrasi dan manajemen pendidikan yang sehat yakni suatu sistem manajemen yang menerapkan fungsi-fungsi manajemen yaitu perencanaan, pengorganisasian, pelaksanaan, pengawasan dan penilaian. Madrasah sebagai wadah untuk mencerdaskan kehidupan bangsa yang merupakan amanah Allah dan amanah Undang-Undang Dasar 1945 melalui pendidikan madrasah sebagai lembaga pendidikan formal yang mengaplikasikan fungsi-fungsi manajemen dalam kegiatan pengelolaannya. ${ }^{20}$

2. Mengintegrasikan manajemen SDM dalam kurikulum, fungsi kurikulum dalam

${ }^{18}$ Philip Kotler, Marketing Management. Alih bahasa, Agus Hasan. Manajemen Pemasaran, Perencanaan, Implementasi, dan Kontrol (Cet. I; Jakarta.: PT. Prenhallindo), h.36.

${ }^{19}$ Ibid, h. 38.

${ }^{20}$ Wina Sanjaya, Perencanaan dan Desain Sistem Pembelajaran (Cet.I; Jakarta: Kencana, 2009), 243. 
rangka pencapaian tujuan pendidikan, kurikulum dapat dipandang sebagai alat untuk pencapaian tujuan pedidikan nasional, dengan menjabarkannya secara berturut menjadi tujuan nasional, tujuan kurikuler dan tujuan instruksional, pada setiap jenis dan jenjang lembaga pendidikan (Madrasah). Kurikulum dalam peningkatan mutu merupakan program pendidikan yang harus diikuti oleh peserta didik atas bimbingan para pendidik untuk mencapai tujuan pendidikan serta sebagai pedoman bagi guru dan peserta didik dalam pelaksanaan proses pembelajaran, agar tujuan pendidikan yang telah ditetapkan benar-benar tercapai. Jenis pengetahuan/keahlian, sikap dan keterampilan yang dimiliki oleh lulusan suatu madrasah dapat diketahui melalui kurikulum madrasah tersebut. Kurikulum merupakan salah satu komponen yang sangat menentukan dalam suatu sistem pendidikan, karena ia merupakan alat untuk mencapai tujuan pendidikan dan sekaligus sebagai pedoman dalam pelaksanaan pengajaran pada semua jenis dan tingkat pendidikan. Tujuan pendidikan di suatu bangsa ditentukan oleh falsafah dan pandangan hidup bangsa atau negara tersebut. Berbedanya falsafah dan pandangan hidup suatu bangsa atau negara menyebabkan berbeda pula tujuan yang hendak dicapai dalam pendidikan tersebut, dan sekaligus akan berpengaruh pula terhadap kurikulum di lembaga-lembaga pendidikan yang ada dalam negara tersebut. ${ }^{21}$ Begitu pula perubahan politik pemerintahan suatu negara mempengaruhi pula bidang pendidikan, yang sering membawa akibat terjadinya perubahan kurikulum yang berlaku. Oleh karena itu, kurikulum perlu diintegrasikan dengan manajemen SDM guna menyesuaikan dengan berbagai perkembangan yang terjadi.

3. Pentingnya manajemen SDM dalam pengajaran di kelas, guru merupakan pendidik yang sangat mempengaruhi kepdibadian peserta didik. Misalnya, apabila tingkah laku pendidik atau guru itu baik, maka tingkah laku peserta didik juga mayoritas baik. Demikian pula sebaliknya, jika sikap atau akhlak pendidik kurang baik, maka jelas pula bahwa sikap atau akhlak peserta didiknya akan kurang baik juga. Karena sikap peserta didik mudah meniru segala tingkah dan perbuatan oleh orang yang disenanginya termasuk guru yang merupakan sosok teladan bagi mereka. Kehadiran guru di Madrasah dan masyarakat merupakan faktor utama dalam mencapai tujuan pendidikan dalam peningkatan mutu dan layanan. Keterampilan seorang guru di dalam merencanakan dan melaksanakan proses pembelajaran merupakan sesuatu yang erat kaitannya dengan tugas dan tanggung jawab guru sebagai pengajar yang mendidik di madrasah dan juga lingkungan masyarakat. Guru sebagai pendidik mengandung arti yang sangat luas, tidak sebatas memberikan bahan-bahan pengajaran tetapi menjangkau etika dan estetika serta manajemen SDM dalam menghadapi tantangan kehidupan di masyarakat. ${ }^{22}$ Guru sebagai pendidik harus

\footnotetext{
${ }^{21}$ Lihat Ramayulis, Ilmu Pendidikan Islam (Cet. II; Jakarta: Kalam Mulia, 1998), h. 65.

${ }^{22}$ Lihat, M. Arifin, Kapita Selekta Pendidikan Islam (Jakarta: Bulan Bintang, 1999), h. 88.
} 
selalu cermat dalam menentukan langkah serta tanggap terhadap situasi dan kondisi. Oleh karena itu, kompetensi merupakan bagian integral yang tidak dapat dipisahkan dari diri seseorang dalam melaksanakan sebuah tugas. Maka dapat dipahami bahwa kompetensi seorang guru merupakan suatu komponen yang harus dimiliki atau dikuasai oleh seorang guru dan sebagai alat untuk memberikan bantuan dan pelayanan terbaik kepada peserta didik dalam proses pembelajaran di kelas.

4. Manajemen SDM untuk mengelola aktifitas evaluasi madrasah. Evaluasi Madrasah merupakan proses yang sangat penting dalam kegiatan pendidikan formal. Evaluasi dapat menentukan evektifitas kinerja selama ini, evaluasi sering dianggap sebagai salah satu hal yang menentukan bagi pengelolaan madrasah dan menentukan kualitas peserta didik. Karena, melalui kegiatan evaluasi dapat ditentukan orientasi dalam proses pengelolaan selanjutnya. Evaluasi mestinya dipandang sebagai sesuatu yang wajar yakni sebagai suatu bagian integral dari suatu proses kegiatan pembelajaran. ${ }^{23}$

Dengan demikian, di era persaingan global seperti sekarang ini, sudah saatnya institusi pendidikan Islam dikembangkan dengan menggunakan pola manajemen ${ }^{24}$ berbasis industri. Pengelolaan model ini menuntut adanya upaya pihak pengelola institusi pendidikan untuk meningkatkan mutu pendidikan dengan berbagai pendekatan seperti pendekatan manajemen SDM dalam peningkatan mutu pendidikan.

Manajemen SDM dalam peningkatan prestasi atau mutu adalah sebuah sistem pendekatan dalam upaya memaksimalkan daya saing melalui perbaikan secara berkesinambungan (terus menerus) untuk memperoleh nilai atau mutu yang optimal atas jasa, manusia, produk dan lingkungan dengan melibatkan keseluruhan unsur dan stakeholders organisasi di bawah satu visi bersama. ${ }^{25}$ Peningkatan mutu pendidikan adalah suatu proses kerja yang lebih efektif dan efisien yang diikuti oleh sumber daya manusia yang berkompeten dengan loyalitas dan daya juang yang tinggi, sudah tentu akan menghasilkan peningkatan kinerja yang berujung pada kepuasan konsumen atau pelanggan. ${ }^{26}$

${ }^{23}$ Wina Sanjaya, op. cit, 246.

${ }^{24}$ Manajemen adalah pusat administrasi, dan administrasi berawal dan berakhir pada manajemen. Manajemen adalah inti dari administrasi. manajemen merupakan sebuah proses dan aktivitas yang melingkar, mulai dari perencanaan, pengorganisasian, pengarahan, sampai dengan pengawasan kemudian kembali lagi pada perencanaan dan seterusnya tidak pernah berhenti, jadi proses administrasi adalah sesuatu yang permulaannya diketahui akan tetapi akhirnya tidak diketahui. Dengan demikian tidak ada pembagian waktu atau langkah yang benar-benar terpisah antara manajemen dan administrasi termasuk supervisi dalam manajemen pendidikan Lihat Sondang P. Siagian, Filsafat Administrasi (Cet. I; Jakarta: Gunung Agung, 1979), h. 18.

${ }^{25}$ Ibid, h. 563

${ }^{26}$ Dede Makbuloh, Manajemen Mutu Pendidikan Islam, Model pengembangan Teori dan Aplikasi Sistem Penjaminan Mutu (Cet. I: Jakarta: PT. Raja grafindo Persada, 2011) h. 4 
Konsep manajemen sumberdaya manusia dalam peningkatan mutu sesungguhnya bukanlah sesuatu yang baru, karena ajaran Islam sebagai Rahmatan li alamin selalu menghendaki agar setiap urusan/pekerjaan harus sesuai dengan tuntunan Islam, sehingga pekerjaan itu dapat bermanfaat bagi diri yang mengerjakannya maupun bagi orang lain. Pekerjaan yang produktif dan yang berkualitas adalah merupakan salah satu perbuatan yang disenangi dalam Islam. Pandangan Islam tentang mutu, sungguh banyak ayat dalam al-Quran, namun harus dipahami secara kontekstual. Islam juga selalu menekankan kepada umatnya untuk selalu berusaha mengubah nasib agar menjadi lebih baik sesuai firmanNya Q.S. Ar-Ra'd/ 13:11

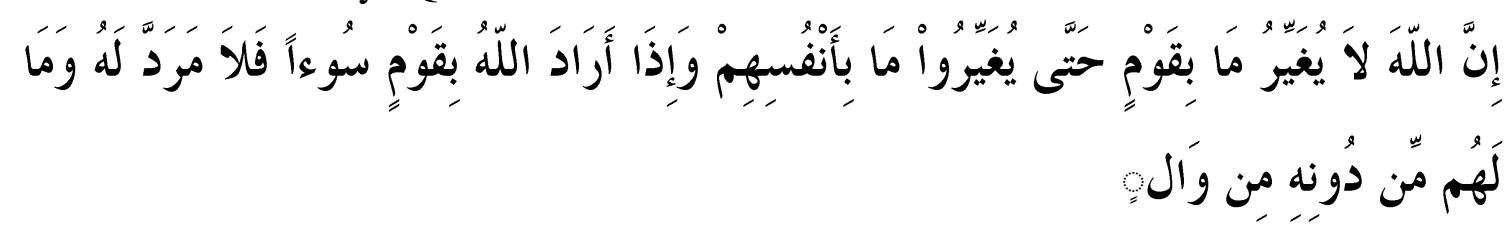

Terjemahnya:

Sesungguhnya Allah tidak akan mengubah nasib suatu kaum kecuali kaum itu sendiri yang mengubah apa yang ada pada diri mereka. ${ }^{27}$

Dalam ayat tersebut jelas sekali bahwa Allah memerintahkan umatnya agar selalu berusaha memperbaiki hidupnya dengan berusaha dan berproduktifitas dalam jalan kebenaran serta berbuat baik pada sesamanya. Produktifitas yang harus dicapai tidak hanya terfokus pada kehidupan duniawi saja, tetapi juga untuk kehidupan akhirat. Konsep produktifitas yang diinginkan dalam Islam adalah konsep yang selalu mengedepankan keseimbangan antara kepentingan ukhrawi dengan kepentingan duniawiyah. Konsep ini sudah berada pada tataran manajemen yang tidak dibatasi oleh ruang dan waktu untuk berusaha mencapai hasil terbaik secara organik dengan menyeimbangkan unsur manusia dan proses produksi yang lebih ditekankan pada pencapaian peningkatan mutu pada usaha atau proses tersebut, sesuai firman Allah Q.S. At-Taubah/9: 105

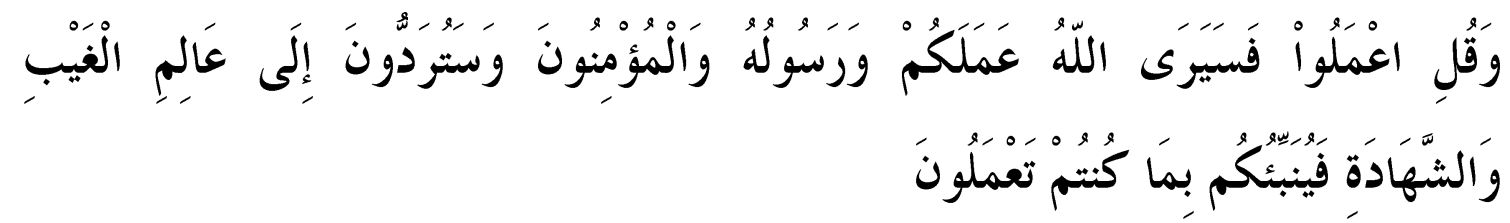

Terjemahnya:

Bekerjalah kamu, maka Allah dan Rasul-Nya serta orang-orang mu'min akan melihat pekerjaanmu itu, dan kamu akan dikembalikan kepada (Allah) Yang Mengetahui akan yang ghaib dan yang nyata, lalu diberitakan-Nya kepada kamu apa yang telah kamu kerjakan. $^{28}$

${ }^{27}$ Departemen Agama RI, Muqaddimah Al Qur'an dan tafsirnya edisi revisi (Cet. II: Jakarta, Lembaga Percetakan Departemen Agama RI, 2009) h.369.

${ }^{28} \mathrm{Ibid}$, h. 280. 
Allah swt menciptakan manusia sebagai mahluk yang sempurna, yang diberikan akal dan pikiran untuk menjalani hidup. Keputusan Allah menciptakan manusia ke bumi bukanlah hal yang sia-sia, manusia diberi kemampuan untuk menjadi khalifah dimuka bumi yang sekaligus membuktikan bahwa kualitas manusia lebih tinggi dan lebih terhormat bila dibandingkan dengan mahluk lainnya, Akan tetapi ada sebuah persyaratan yang harus dipenuhi agar manusia dikatakan manusia yang unggul atau berkualitas yaitu memiliki sumberdaya yang bagus.

Secara filosofis, konsep manajemen SDM dalam peningkatan prestasi menekankan pada pencarian secara konsisten terhadap perbaikan yang berkelanjutan untuk mencapai kebutuhan dan kepuasan pelanggan. manajemen SDM dalam peningkatan mutu dalam pendidikan sudah mendapatkan perhatian serius dari para tokoh pendidikan, baik dari dalam maupun dari luar Indonesia. Hal ini menunjukkan bahwa manajemen peningkatan mutu dan isu-isu mutu secara umum mengundang perhatian publik. Dalam beberapa tahun terakhir, isu tersebut semakin meningkat. Masyarakat dari semua sektor pendidikan sekarang telah menunjukkan minatnya. Beberapa institusi pendidikan mulai mewujudkan filosofi manajemen peningkatan prestasi ke dalam pengelolaan manajemen pendidikan. ${ }^{29}$

Salah satu masalah penting di dalam dunia pendidikan adalah masih rendahnya mutu keluarannya. Indikator yang menjadi acuan untuk menguatkan pernyataan tersebut adalah Nilai Ujian Nasional yang secara umum belum terlalu menggembirakan, artinya batas minimal kelulusan masih rendah dibandingkan negara tetangga. Upaya meningkatkan mutu pendidikan telah lama diprogramakan oleh pemerintah dengan merumuskan misi pendidikan nasional sebagai strategi pembangunan dibidang pendidikan sebagai berikut;

1. Perluasan kesempatan dan pemerataan memperoleh pendidikan yang bermutu bagi seluruh rakyat Indonesia.

2. Meningkatkan mutu pendidikan yang memiliki daya saing di tingkat nasional, regional dan internasional.

3. Meningkatan relevansi pendidikan dengan kebutuhan masyarakat dan tantangan global.

4. Membantu dan menfasilitasi pengembangan potensi anak bangsa secara utuh sejak usia dini sampai akhir hayat dalam rangka mewujudkan masyarakat belajar.

5. Meningkatkan kesiapan masukan dan kualitas proses pendidikan untuk mengoptimalkan pembentukan kepribadian yang bermoral.

6. Meningkatkan keprofesionalan dan akuntabilitas lembaga pendidikan sebagai pusat pembudayaan ilmu pengetahuan, keterampilan, pengalaman, sikap dan nilai berdasarkan standar yang bersifat nasional dan global.

7. Mendorong peran serta masyarakat dalam penyelenggaraan pendidikan berdasarkan

${ }^{29}$ Ibid, h. 6 
prinsip otonomi dalam konteks Negara Kesatuan Republik Indonesia. ${ }^{30}$

Pada sisi lain secara internal, hal tersebut disebabkan oleh penerapan pendekatan input-output yang keliru. Pihak pengelola terlalu mengedepankan aspek input oriented yang lebih bersandar pada asumsi bahwa bilamana semua input pendidikan telah dipenuhi, misalnya kekurangan guru, ditambah guru, membangun laboratorium, dan seterusnya, maka secara otomatis lembaga pendidikan (sekolah/madrasah) akan dapat menghasilkan output (keluaran) yang bermutu sebagaimana yang diharapkan. ${ }^{31}$ Padahal ada satu faktor yang terlupakan, yaitu bagaimana berbagai input tersebut dipertemukan dan berinteraksi di dalam proses pembelajaran, yang diperkuat dengan dukungan manajemen sumberdaya manusia yang efektif. ${ }^{32}$

Peningkatan mutu atau kualitas pembelajaran merupakan inti dari reformasi pendidikan di negara manapun. Hal ini disebabkan oleh asumsi bahwa, peningkatan mutu pendidikan pada madrasah yang memiliki peran penting dalam peningkatan mutu pendidikan nasional, tergantung pada kualitas pembelajaran. Namun, peningkatan kualitas pembelajaran sangat bersifat kontekstual, sangat dipengaruhi oleh kondisi sosial dan kultural madrasah dan lingkungannya. Berbagai penelitian menunjukan bagaimana pentingnya kondisi dan lingkungan madrasah mempengaruhi kualitas pembelajaran, seperti dalam penelitian tentang sekolah efektif, kerja guru dan pembelajaran, restrukturisasi sekolah/madrasah dan kinerja organisasi yang semuanya ini bermuara pada suatu pernyataan, "apabila ingin meningkatkan kualitas pembelajaran, kualitas sekolah sebagai satu kesatuan di mana pembelajaran berlangsung harus ditingkatkan"

Gambaran di atas menunjukkan perlunya sebuah perubahan paradigma yang harus dilakukan secara bersama-sama antara pimpinan, tenaga pendidik dan karyawan sehingga mereka mempunyai langkah dan strategi yang sama yaitu menciptakan mutu di lingkungan kerja khususnya pada madrasah di Sulawesi-Selatan. Pimpinan, tenaga pendidik dan kependidikan serta karyawan harus menjadi satu tim yang utuh (team work) yang saling membutuhkan dan saling mengisi kekurangan yang ada sehingga target (goals) akan tercipta dengan baik.

Mutu produk pendidikan akan dipengaruhi oleh sejauh mana lembaga mampu mengelola seluruh potensi secara optimal mulai dari tenaga kependidikan, peserta didik, proses pembelajaran, sarana pendidikan, keuangan dan termasuk hubungannya dengan masyarakat. Pada kesempatan ini, lembaga pendidikan Islam harus mampu merubah paradigma baru pendidikan yang berorientasi pada mutu semua aktifitas yang berinteraksi didalamnya, seluruhnya mengarah pencapaian pada mutu. ${ }^{33}$

\footnotetext{
${ }^{30}$ Kementerian Agama RI, Direktorat Jenderal Pendidikan Islam, op.cit, h. 196.

${ }^{31}$ Ibid, h. 9 .

${ }^{32}$ Ety Rochaety Pontjorini, dkk. Sistem Informasi Manajemen Pendidikan, (Cet.I; Jakarta: Bumi Aksara, 2006) h. 97.

${ }^{33}$ Peningkatan mutu meliputi enam unsur dasar yang mempengaruhi suatu produk yakni 1) Manusia 2) Metode 3) Mesin 4) Bahan 5) Ukuran dan 6) Evaluasi Berkelanjutan. Demikian juga dalam
} 
Manajemen sumberdaya manusia dalam peningkatan mutu bertujuan mengubah institusi yang mengoperasikannya menjadi sebuah tim yang ikhlas, tanpa konflik dan kompetisi internal, untuk meraih sebuah tujuan tunggal, yaitu memuaskan pelanggan. ${ }^{34}$ Dalam konteks manajemen peningkatan mutu pelanggan dalam dunia pendidikan dapat dibedakan menjadi 2 (dua) macam yaitu 1). pelanggan internal yaitu para pengelola sekolah seperti guru, pustakawan, laboran, teknisi dan tenaga administrasi; 1) pelanggan eksternal yang terbagi menjadi: (a) pelanggan primer yaitu siswa. 2) pelanggan sekunder yaitu orang tua, pemerintah, dan sponsor; (b) pelanggan primier seperti perguruan tinggi dan dunia kerja yang menerima lulusan madrasah.

\section{PENUTUP}

1. Hakikat manajemen sumber daya terhadap peningkatan mutu adalah suatu sistem implementasi dalam menjalankan suatu usaha pendidikan yang berusaha memaksimumkan daya saing melalui penyempurnaan terus menerus dalam meningkatkan kualitas pendidikan secara totalitas

2. Implementasi Manajemen SDM dalam peningkatan mutu merupakan sebuah sistem pendekatan dalam upaya memaksimalkan daya saing melalui perbaikan secara berkesinambungan (terus menerus) untuk memperoleh nilai atau mutu yang optimal atas jasa, manusia, produk dan lingkungan dengan melibatkan keseluruhan unsur dan stakeholders organisasi di bawah satu visi bersama. Peningkatan mutu pendidikan adalah suatu proses kerja yang lebih efektif dan efisien yang diikuti oleh sumber daya manusia yang berkompeten dengan loyalitas dan daya juang yang tinggi, sudah tentu akan menghasilkan peningkatan kinerja yang berujung pada kepuasan konsumen atau pelanggan.

\section{DAFTAR PUSTAKA}

al Attas, Syed Muhamad Naquib Konsep Pendidikan dalam Islam : Suatu Rangka Pikir Pembimbing Filsafat Pendidikan Islam. Cet. I; Bandung: Mizan, 2009.

Daulat P. Tampubolon, Perguruan Tinggi Bermutu: Paradigma Baru Manajemen Pendidikan Tinggi Menghadapi Abad ke-21. Cet. I; Jakarta: PT. Gramedia Pustaka Utama: 2011.

Departemen Pendidikan Nasional, Kamus Besar Bahasa Indonesia Jakarta: Balai Pustaka, 2008.

pendidikan, bahwa keenam hal tersebut cocok untuk dijadikan pedoman dalam menyusun manajemen, khususnya administrasi pendidikan. Lihat Suryadi Poerwanegara, Filosofi Baru Tentang Manajemen Mutu Terpadu. (Cet. I; Jakarta: PT. Bumi Aksara. 2002) h. 12.

${ }^{34}$ Lihat Edward Sallis, op.cit, h. 69. 
Departemen Agama RI, Muqaddimah Al Qur'an dan tafsirnya edisi revisi. Cet. II: Jakarta, Lembaga Percetakan Departemen Agama RI, 2009

Depatemen Agama, Profil Madrasah Masa Depan. Cet. I; Jakarta: Direktorat Jenderal Pendidikan Islam, 2006.

E. Mulyasa, Menjadi guru Profesional: Menciptakan Pembelajaran Kreatif dan Menyenangkan. Cet.X; Bandung: Remaja Rosdakarya, 2011.

Kementerian Pendidikan Nasional, Dirjen Peningkatan Mutu Pendidik dan Tenaga Kependidikan(PMPTK), Direktorat Tenaga Kependidikan Penilaian Kinerja Guru dan kompetensi evaluasi Pendidikan, th. 2008, h. 1.

M. Arifin, Kapita Selekta Pendidikan Islam. Jakarta: Bulan Bintang, 1999.

Majlis Pertimbangan dan Pemberdayaan Pendidikan Agama dan Keagamaan (MP3A), Direktorat Jenderal Pendidikan Agama Islam, Kementeria Agama RI, Revitalisasi Madrasah dalam Menghadapi Persaingan Global, Jurnal Voleme 1, 2 Maret 2006.

Makbuloh, Dede. Manajemen Mutu Pendidikan Islam, Model pengembangan Teori dan Aplikasi Sistem Penjaminan Mutu. Cet. I: Jakarta: PT. Rajagrafindo Persada, 2011

Mantja, William Manajemen Peningkatan Mutu Pendidikan.Cet. I: Jakarta: LIPI, 2000

Nata, Abuddin. Manajemen Pendidikan Mengatasi Kelemahan Pendidikan Islam di Indonesia. Cet. I; Jakarta: Kencana Prenada Media Group, 2008.

Philip Kotler, Marketing Management. Alih bahasa, Agus Hasan. Manajemen Pemasaran, Perencanaan, Implementasi, dan Kontrol. Cet. I; Jakarta.: PT. Prenhallindo), h.36.

Pius A. Partanto dan M Dahlan al-Barry, Kamus llmiah Poputer Surabaya: Arkola, 1994.

Ramayulis, Ilmu Pendidikan Islam. Cet. II; Jakarta: Kalam Mulia, 1998.

Shaleh, Abdul Rahman Penyelenggaraan Madrasah. Cet. II; Jakarta: Dharma Bakti, 2013.

Soetjipto, Budi W., dkk., Paradigma Baru Manajemen Sumber Daya Manusia Cet. II; Yogyakarta: Amara Book, 2012.

Sondang P. Siagian, Filsafat Administrasi Cet. I; Jakarta: Gunung Agung, 1979. 18.

Supriyadi, Dedi. Mengangkat citra dan martabat Guru. Cet. I; Yogyakarta: Adicipta Karya Nusa, 1998.

Wahjosumidjo, Kepemimpinan Kepala Sekolah. Cet. I; Jakarta: Raja Grafindo Persada, 2010. 
Wina Sanjaya, Perencanaan dan Desain Sistem Pembelajaran. Cet.I; Jakarta: Kencana, 2009. 